\title{
Menopause and work: An overview of UK guidance
}

ABSTRACT:

Background: Recent evidence suggests that some women experience menopausal symptoms that impact on their working lives, and that work environments can impact upon the experience of menopause. As a result, guidance for employers and other key stakeholders about this potential occupational health issue has emerged. To date there has not been a review of these documents to identify their main recommendations for policy and practice.

Aims: To provide a narrative overview of such guidance and summary of content.

Methods: Documents published in the United Kingdom and available in a major UK trade union library were searched systematically to identify guidance on the topic of menopause and work. An inductive thematic analysis was performed to identify the main themes addressed.

Results: 25 relevant documents, on average eight pages long, were identified. A minority indicated that the use of scientific evidence informed the content. Five overarching themes were identified: 1) legislation; 2) policy; 3) information and training needs; 4) workplace support; and 5) the physical work environment.

Conclusions: This overview of UK guidance revealed common areas of concern about reducing and managing difficulties experienced by working menopausal women. Possible areas for action were identified. Some recommendations were common across much of the guidance, whereas others were exclusive. Future guidance might include consideration of all these issues, while making reference both to the evidence base and sources of further information.

KEY WORDS: menopause, work, guidance, review, employer, trade union, United Kingdom. 


\section{INTRODUCTION}

Increasing attention is being given to the topic of menopause and work. There is a growing number of employed women aged 50 years and over [1]. A recent report for the UK government on older workers highlighted that more women are now working through their menopause than before, and emphasised the importance of retaining mid-aged and older women in the workforce [2].

Irregular periods signal the beginning of the menopausal transition and the perimenopause phase. When 12 months have passed since her final menstrual period, a woman is said to be in her postmenopause phase [3]. A wide range of symptoms is reported by women during these phases. The most common are hot flushes and night sweats, which, if severe, can impact on quality of life [4]. These and other menopausal symptoms can be perceived as problematic in the workplace, often because of embarrassment and stigma [5-7]. Certain work factors can make hot flushes more difficult to deal with: for example, formal meetings and hot enclosed spaces[6]. Many women are reluctant to disclose their menopausal status or related difficulties at work [5-10].

A large scale study in the UK explored the experience of women working though the menopause [9]. This involved over 60 interviews and an electronic survey of almost 900 women from ten organisations. Poor concentration, tiredness, poor memory, feeling low/depressed and lowered confidence were the symptoms they attributed to menopause and identified as having a negative impact on their working life. Hot flushes at work were reported as difficult for some women, particularly in hot or poorly ventilated workspaces, in formal meetings and high visibility work such as presentations. Although there were no objective measures of work performance in this study, the majority of women in this sample reported that their work performance had not been negatively affected. However, some did report concerns about their performance, and some put in extra effort in order that their job performance was not affected. The majority were unwilling to disclose their menopause to line managers, particularly if their managers were male or younger than them. Five key areas were identified by women for employer support: 1) management awareness of menopause as 
a possible health problem, 2) flexible working hours, 3) information about coping with menopause and work, 4) better control over temperature and ventilation, and 5) access to informal sources of support, such as women's networks or telephone help-lines. In a later study, women identified similar sources of desirable support as well as examples of desirable manager communication skills. [11]. Such findings need to be communicated and guidance is one way of addressing this aim.

In the UK over recent years, guidance for women, employers and trade union representatives on dealing with the menopause and work has been published. The content of such guidance, and to what extent its content is common and evidence-based, has not been examined. The aim of this paper was to present a narrative overview of UK guidance on menopause and work.

\section{METHODS}

At the time of this study, 161 UK trade unions and federations were identified from the Trade Union Congress (TUC) website and the internet. The TUC is the largest UK trade union federation. Its website and those of each trade union were searched for relevant guidance about menopause and work published up to, and including, November 2016. Some union websites restricted access to members and some had no search functions. Resources within a large UK trade union library were searched manually to identify any guidance unavailable online. An internet search (using Google search engine) was also conducted to identify guidance from other sources. Results were screened by the first author for relevance. Irrelevant hits (e.g., those results or documents not addressing menopause and work, nor providing information, guidance or advice) were excluded. Relevant documents were inserted into the software tool NVivo (version 10) for analysis. Ethical approval was not deemed necessary as the study involved analysis of data in the public domain.

An inductive thematic analysis was performed [12]. This allowed the identification of themes (also known as codes, nodes or categories). All information was extracted and analysed at surface-level (explicit) meaning. This approach relies on direct interpretation of the data as opposed to researchers 
theorising about underlying meaning. Using this approach stays close to the raw data and produces low inference descriptors [13], serving to enhance reliability.

The first author performed the initial analysis and created an initial thematic structure. The third author reviewed the data and initial thematic structure to assess its adequacy and accuracy. Both authors reviewed the themes and their descriptors. Some were combined to represent the content more concisely. Through discussion, the thematic structure was refined and finalised. All authors reviewed and agreed the final themes.

\section{RESULTS}

A total of 25 relevant documents were identified and included in this overview (see Table 1). The clear majority was produced by trade unions with the remainder generated by employer and professional bodies. Not all clearly indicated their date of publication but we were able to establish publication dates ranged from 1991 to 2016. From our search, most guidance was produced during 2015 and 2016. Figure 1 shows the number of guidance publications over time. The rise in number may reflect reactions to the guidance produced by the British Occupational Health Research Foundation 2010[14], which informed several of the subsequent guidance publications.

The length of the guidance varied from less than a page to 18 pages, with an average length of eight pages. Some guidance specifically focused on menopause and work, whereas other guidance appeared within a broader document covering working women's health more generally. Some materials were almost identical to others or reflected, in at least one instance, a revision to reflect a union's change of name. Most guidance included a section with the sources of their information. Some, however, did not provide such details. When reviewing the materials, we also explored these sources and the scientific evidence base referred to in each document. The most frequently reported sources were guidance published by the TUC and guidance produced by the British Occupational Health Research Foundation [14]. Few documents made references to published scientific papers. 
[Table 1 about here]

Five overarching themes were identified: legislation, organisational policies, information and training, workplace support, and the physical work environment. Each of these themes is briefly described in Table 2 and in more detail in the following section.

[Table 2 about here]

Legislation: Almost all of the guidance documents reviewed highlighted the authors' views on the importance of employers' common law duty of care for their employees' health and safety and relevant legislation such as the Health and Safety at Work Etc Act 1974, and the Management of Health and Safety at Work Regulations 1992 and 1999. The guidance from Unite considered how the latter Regulations were relevant.

"These regulations are very important in the context of the menopause. They cover a wide range of workplace requirements including maintenance, ventilation, temperature, access and egress, lighting, cleanliness of the workplace, sanitary and washing facilities, eating facilities and restrooms, changing facilities, drinking water, space in workrooms, workstations and seating requirements, employers' duty to protect employees from effects of sunlight and provision relating to disabled workers." (Unite)

The guidance found in our review commonly explained the importance of including consideration of menopause when conducting risk assessments.

The Equality Act 2010 was cited in most guidance with reference to discrimination and disability.-Three of the eight protected characteristics, age, gender and disability were considered relevant for menopausal women. 
Disability was mentioned in several of the guidance publications, noting that the menopause has the potential to be classed as a disability should symptoms have a significant impact for more than twelve months.

$$
\begin{aligned}
& \text { "Severe menopausal symptoms and their consequences may combine to have a } \\
& \text { substantial adverse effect on normal day to day activities - potentially meeting the legal } \\
& \text { definition of a disability under the Equality Act." (Faculty of Occupational Medicine (FOM)) }
\end{aligned}
$$

Policy: Employers' policies relating to sickness absence, flexible working and health and wellbeing were frequently mentioned in the guidance we reviewed. With regard to sickness absence, policies were described that allow flexibility and allowable sickness absence for menopausal women to accommodate needs for temporary changes in working patterns, more breaks than usual, and for medical appointments.

"Policies on flexible working and sickness absence should also recognise and support female employees going through the menopause, for example by considering temporary changes in work/shift patterns or recognising that sickness absence may be more frequent as employees struggle with symptoms such as excessive bleeding or sleep deprivation." (Royal College of Nursing)

Other guidance pointed out the need for employers to be flexible in order to accommodate difficulties or situations that may not always be predictable. The FOM guidance, for example, pointed out that later start times can be helpful when sleep is disturbed.

Having a health and wellbeing policy that incorporates menopause was also suggested as useful, not least so that menopause might be recognised as an potential occupational health issue. The Royal 
College of Nursing's guidance suggested that such approaches also serve to raise managers' and colleagues' awareness.

Less frequently, guidance gave examples of policy documents, agreements and checklists designed to help ensure-that the menopause was being addressed.

Information and training: Almost unanimously, the published guidance on menopause referred to the importance of workplace provision of information and training for managers, trade union representatives and menopausal women. Several publications stated the importance of educating all staff about the menopause.

"Employers can ensure that, as part of a wider occupational health awareness campaign, issues such as the menopause are highlighted so all staff know that the employer has a positive attitude to the issue, and that it is not something that women should feel embarrassed about." (TUC)

The importance of training for key stakeholders within organisations was consistently presented. In particular, this included trade union representatives and line managers, who are in key positions to provide support.

Providing information for women was mentioned in much of the guidance. This included information about sources of support in the workplace.

Guidance also provided practical advice for women about how they could explore ways of managing their symptoms. This included advice about coping strategies whilst at work and outside work. Some guidance described helpful strategies with regard to clothing, such as wearing layers and items such as cardigans which are easily removed. The FOM guidance suggested that women might consider using 
techniques such as mindfulness or cognitive behavioural therapy.

Support: The provision of support at work for menopausal women was advocated in all the guidance we reviewed. Access to both informal and formal support from a variety of possible sources was considered important, and as described above, line managers were considered central in this respect.

"Women who are experiencing the menopause need support from line management. With any longstanding health-related condition this is crucial and can make a major difference to how a woman will deal with the issues arising from the menopause." (UNISON)

However, it was noted that not all women feel comfortable discussing such personal matters with their immediate line managers.

"Women may feel uncomfortable going to their line manager, especially if it is a man, and other options should be available. This may be through human resources, or a welfare officer. Many employers have employee assistance programmes that can act as a gobetween." (TUC)

As well as the sources of support suggested in the example above others included occupational health, GPs, counsellors, peers, a network or named menopause contact person within the organisation. Trade union representatives were frequently suggested as providing a key role in supporting women but also in raising awareness and facilitating change.

Physical work environment: The final theme related to the physical working environment in relation to women's experience of menopause. For example, frequently mentioned as helpful were readily available cold drinking water, access to sanitary and toilet facilities, and adequate control over temperature and ventilation. Also advocated were fans at workstations, desks near opening windows 
and more control over heating and air conditioning.

Uniforms, and their impact on women's menopausal symptoms, particularly hot flushes, were also considered in a few of the examples of guidance. It was suggested that uniforms could be manufactured with thermally comfortable fabrics and staff could be provided with optional layers and permitted to remove neckties or jackets. The provision of changing facilities was also proposed as helpful.

\section{DISCUSSION}

The findings of this review suggest consensus that menopause is a potential occupational health issue and identified five themes: legislation; 2) policy; 3) information and training needs; 4) workplace support; and 5) the physical work environment. However most guidance about menopause and work made it clear that although potentially problematic, severe menopausal symptoms were not experienced by most women.

A recent systematic review of menopause and work identified 75 published studies and reports, many of which have emerged in the last five years [10]. However, the majority of guidance we reviewed did not refer to this evidence base. It is therefore not possible to conclude whether existing UK guidance has fully exploited the available evidence. Future guidance might do so and be regularly updated as more evidence emerges.

To the authors' knowledge, this is the first overview of guidance on menopause and working life. A key strength is that it followed a systematic approach to identify relevant documentation. Its limitations include the fact that it only examined publicly available guidance obtained via the internet and a major UK trade union library. It is possible that we missed some publically available guidance and that in-house guidance has been produced, for example, by employers. Their content may not 
reflect the dominant themes identified here. Guidance from other countries may produce different results, notably concerning legislation. A wider review of guidance might identify commonalities and differences across countries and cultures.

Overall, our findings might suggest that employers could: 1) explore how well their existing policies and practices, including risk assessments, address the menopause related concerns identified in this review, 2) consider the development of policies and guidance that specifically address menopause, 3) investigate the knowledge and skills of staff, particularly line managers, and identify training needs.

In conclusion, evidence to date suggests that menopause presents problems for some of the UK's increasing number of working women. While the results of this review are encouraging in that published guidance is becoming more available, it is not yet known to what extent recommendations that appear in such guidance are being implemented by employers and whether they are effective. A recent review of the effects of the menopause on women's economic participation suggested that the evidence thus far was inconclusive [15]. Future research might explore these issues.

\section{Key points:}

- A review of guidance on menopause and work in the UK revealed five keys themes: 1) legislation; 2) policy; 3) information and training needs; 4) workplace support; and 5) the physical work environment.

- Implications for employers include 1) exploring how well their existing policies and practices, including risk assessments, address menopause related issues 2) considering the development of policies and guidance that specifically address menopause, and 3) investigating the knowledge and skills of employees, particularly line managers, and identifying training needs. 
- There remains a need to find out whether the recommendations provided in guidance on menopause and work are being implemented and are effective. 


\section{REFERENCES}

[1] Office of National Statistics (ONS). Table A05: Labour market by age group: Women by economic activity and age (seasonally adjusted); Jan 2017. [Online]. Available from: https://www.ons.gov.uk/employmentandlabourmarket/peopleinwork/employmentandemplo yeetypes/datasets/employmentunemploymentandeconomicinactivitybyagegroupseasonallya djusteda05sa [Accessed 17th February 2017].

[2] Altmann R. A new vision for older workers: retain, retrain, recruit. London: Department for Work and Pensions. 2015.

[3] Soules MR, Sherman S, Parrott E, Rebar R, Santoro N, Utian W, Woods N. Executive summary: stages of reproductive aging workshop (STRAW). Climacteric. 2001 Jan 1;4(4):267-72.

[4] Ayers B, Hunter MS. Health-related quality of life of women with menopausal hot flushes and night sweats. Climacteric. 2013 Apr 1;16(2):235-9.

[5] Morris ME, Symonds A. 'We've been trained to put up with it': real women and the menopause. Critical Public Health. 2004 Sep 1;14(3):311-23.

[6] Hunter MS, Liao K. A psychological analysis of menopausal hot flushes. British Journal of Clinical Psychology. 1995 Nov 1;34(4):589-99.

[7] Smith MJ, Mann E, Mirza A, Hunter MS. Men and women's perceptions of hot flushes within social situations: Are menopausal women's negative beliefs valid? Maturitas. 2011 May 31;69(1):5762.

[8] Reynolds F. Distress and coping with hot flushes at work: implications for counsellors in occupational settings. Counselling Psychology Quarterly. 1999 Dec 1;12(4):353-61.

[9] Griffiths A, MacLennan SJ, Hassard J. Menopause and work: an electronic survey of employees' attitudes in the UK. Maturitas. 2013 Oct 31;76(2):155-9.

[10] Jack G, Riach K, Bariola E, Pitts M, Schapper J, Sarrel P. Menopause in the workplace: what employers should be doing. Maturitas. 2016 Mar 31;85:88-95.

[11] Hardy C, Griffiths A, Hunter MS. What do working menopausal women want? A qualitative investigation into women's perspectives on employer and line manager support. Maturitas. 2017 Jul 31;101:37-41.

[12] Braun V, Clarke V. Using thematic analysis in psychology. Qualitative research in psychology. 2006 Jan 1;3(2):77-101.

[13] Silverman D. Interpreting qualitative data: Methods for analyzing talk, text and interaction. Sage; 2001.

[14] British Occupational Health Foundation (2010). Work and the menopause: a guide for managers. [Online].

Available from: http://www.bohrf.org.uk/downloads/Work and the Menopause-

A Guide for Managers.pdf (Accessed 17th February 2016). 
[15] Brewis J, Beck V, Davies A, Matheson J. The effects of menopause transition on women's economic participation in the UK. 2017 Report for the Department for Education, UK. Available from: $\quad$ https://www.gov.uk/government/publications/menopause-transition-effects-onwomens-economic-participation [accessed 15th August 2017]. 


\begin{tabular}{|c|c|c|c|c|c|c|c|}
\hline & Author & Type & $\begin{array}{l}\text { Focused/ } \\
\text { Embedded }\end{array}$ & Year & Title & Length & Accessed \\
\hline 1. & $\begin{array}{l}\text { Faculty of Occupational } \\
\text { Medicine (FOM) }\end{array}$ & $\begin{array}{l}\text { Professional } \\
\text { organisation }\end{array}$ & Focused & 2016 & $\begin{array}{l}\text { Guidance on menopause and } \\
\text { the workplace }\end{array}$ & 4 pages & $\begin{array}{l}\text { https://www.som.org.uk/sites } \\
\text { /som.org.uk/files/Guidance- } \\
\text { on-menopause-and-the- } \\
\text { workplace.pdf }\end{array}$ \\
\hline 2. & $\begin{array}{l}\text { Fire Brigades Union } \\
\text { (FBU) }\end{array}$ & Trade union & Focused & 2016 & $\begin{array}{l}\text { FBU Good Practice Guidance } \\
\text { for Menopause }\end{array}$ & 2 pages & $\begin{array}{l}\text { https://www.fbu.org.uk/publi } \\
\text { cation/fbu-good-practice- } \\
\text { guidance-menopause }\end{array}$ \\
\hline 3. & $\begin{array}{l}\text { Royal College of Nursing } \\
\text { (RCN) }\end{array}$ & $\begin{array}{l}\text { Professional } \\
\text { organisation } \\
\text { and trade union }\end{array}$ & Focused & 2016 & $\begin{array}{l}\text { The Menopause and Work: } \\
\text { Guidance for RCN } \\
\text { Representatives }\end{array}$ & 12 pages & $\begin{array}{l}\text { https://www.rcn.org.uk/profe } \\
\text { ssional- } \\
\text { development/publications/pu } \\
\underline{\text { b-005467 }}\end{array}$ \\
\hline 4. & $\begin{array}{l}\text { Royal College of } \\
\text { Midwives (RCM) }\end{array}$ & $\begin{array}{l}\text { Professional } \\
\text { organisation } \\
\text { and trade union }\end{array}$ & Focused & 2016 & $\begin{array}{l}\text { Working with the } \\
\text { Menopause }\end{array}$ & 18 pages & $\begin{array}{l}\frac{\text { https://www.rcm.org.uk/sites }}{\text { /default/files/Equality\%20and }} \\
\text { \%20Diversity\%20Publication\% } \\
\text { 20- } \\
\text { \%20Working\%20with\%20the } \\
\text { \%20Menopause\%2020pp\%20 } \\
\text { A5 7.pdf }\end{array}$ \\
\hline 5. & UNISON & Trade Union & Embedded & 2016 & $\begin{array}{l}\text { Women's Reproductive } \\
\text { Health Issues }\end{array}$ & $\begin{array}{l}3 \text { pages } \\
\left(1 / 5^{\text {th }} \text { page }\right. \\
\text { on } \\
\text { menopause })\end{array}$ & $\begin{array}{l}\text { https://www.unison.org.uk/c } \\
\text { ontent/uploads/2016/01/Wo } \\
\text { mens-reproductive-health- } \\
\text { issues.pdf }\end{array}$ \\
\hline
\end{tabular}




\begin{tabular}{|c|c|c|c|c|c|c|c|}
\hline 6. & $\begin{array}{l}\text { National Association of } \\
\text { Schoolmasters Union of } \\
\text { Women Teachers } \\
\text { (NASUWT) }\end{array}$ & Trade Union & Focused & 2016 & $\begin{array}{l}\text { Managing the Menopause in } \\
\text { the Workplace }\end{array}$ & 8 pages & $\begin{array}{l}\text { https://www.nasuwt.org.uk/u } \\
\text { ploads/assets/uploaded/0983 } \\
\text { e7b0-019e-4b46- } \\
\underline{\text { 87a9cdef2537a6b7.pdf }}\end{array}$ \\
\hline 7. & $\begin{array}{l}\text { Union of Shop, } \\
\text { Distributive and Allied } \\
\text { Workers (USDAW) }\end{array}$ & Trade Union & Focused & 2016 & $\begin{array}{l}\text { Women's Equality Women's } \\
\text { Health - The Menopause }\end{array}$ & 6 pages & $\begin{array}{l}\text { https://www.usdaw.org.uk/C } \\
\text { MSPages/GetFile.aspx?guid=1 } \\
\text { ceef9c0-8be1-427d-acf2- } \\
\underline{\text { c11440852402 }}\end{array}$ \\
\hline 8. & $\begin{array}{l}\text { Broadcasting, } \\
\text { Entertainment, } \\
\text { Cinematograph and } \\
\text { Theatre Union (BECTU) }\end{array}$ & Trade Union & Embedded & 2015 & $\begin{array}{l}\text { Women's Health and Safety } \\
\text { Issues }\end{array}$ & $\begin{array}{l}6 \text { pages (1 } \\
\text { page focused } \\
\text { on } \\
\text { menopause) }\end{array}$ & $\begin{array}{l}\text { https://www.bectu.org.uk/ad } \\
\text { vice-resources/library/1884 }\end{array}$ \\
\hline 9. & Bridgewater NHS Trust & $\begin{array}{l}\text { Health care } \\
\text { employer }\end{array}$ & Focused & 2015 & $\begin{array}{l}\text { The Last Taboo - Managing } \\
\text { the Menopause in the } \\
\text { Workplace }\end{array}$ & 5 pages & $\begin{array}{l}\text { http://www.bridgewater.nhs. } \\
\text { uk/wp- } \\
\text { content/uploads/2014/02/Me } \\
\underline{\text { nopause-Briefing.pdf }}\end{array}$ \\
\hline 10. & $\begin{array}{l}\text { National Union of } \\
\text { Teachers (NUT) }\end{array}$ & Trade union & Focused & 2014 & $\begin{array}{l}\text { Teachers Working though } \\
\text { the Menopause: Guidance } \\
\text { for members in England and } \\
\text { Wales }\end{array}$ & 10 pages & $\begin{array}{l}\underline{\text { https://www.teachers.org.uk/ }} \\
\text { files/menopause-a4-for-web-- } \\
\underline{\text { 9968-.pdf }}\end{array}$ \\
\hline 11. & $\begin{array}{l}\text { Trade Union Congress } \\
\text { (TUC) }\end{array}$ & Trade Union & Focused & 2013 & $\begin{array}{l}\text { Supporting Working Women } \\
\text { through the Menopause: } \\
\text { Guidance for Union } \\
\text { Representatives }\end{array}$ & 12 pages & $\begin{array}{l}\text { https://www.tuc.org.uk/sites/ } \\
\underline{\text { default/files/TUC menopause }} \\
\underline{0 . p d f}\end{array}$ \\
\hline
\end{tabular}




\begin{tabular}{|c|c|c|c|c|c|c|c|}
\hline 12. & UNISON & Trade Union & Focused & 2013 & $\begin{array}{l}\text { The menopause and work: A } \\
\text { guide for UNISON safety reps }\end{array}$ & 8 pages & $\begin{array}{l}\frac{\text { https://www.unison.org.uk/c }}{\text { ontent/uploads/2013/06/On- }} \\
\underline{\text { line-Catalogue204723.pdf }}\end{array}$ \\
\hline 13. & UNISON & Trade Union & Focused & 2013 & Menopause Factsheet & 2 pages & $\begin{array}{l}\frac{\text { https://www.unison.org.uk/c }}{\text { ontent/uploads/2013/08/Brie }} \\
\text { fings-and- } \\
\text { CircularsMenopause- } \\
\text { Factsheet3.pdf }\end{array}$ \\
\hline 14. & $\begin{array}{l}\text { National Union of Rail, } \\
\text { Maritime and Transport } \\
\text { Workers (RMT) }\end{array}$ & Trade Union & Embedded & 2013 & Women's Charter & 1 page & $\begin{array}{l}\text { https://www.rmt.org.uk/news } \\
\text { /publications/womens- } \\
\text { charter/ }\end{array}$ \\
\hline 15. & Unite & Trade Union & Embedded & 2012 & $\begin{array}{l}\text { Working Women Stronger } \\
\text { Together: Women's Health, } \\
\text { Safety and Well-being at } \\
\text { Work - Negotiators' Guide }\end{array}$ & $\begin{array}{l}82 \text { pages (11 } \\
\text { focused on } \\
\text { menopause) }\end{array}$ & $\begin{array}{l}\text { http://www.unitetheunion.or } \\
\text { g/uploaded/documents/Wom } \\
\text { en\%27s\%20Health,\%20Safety } \\
\text { \%20\%26\%20Well- } \\
\text { being\%20at\%20Work\%20(Uni } \\
\text { te\%20guide)11-5062.pdf }\end{array}$ \\
\hline 16. & $\begin{array}{l}\text { Associated Society of } \\
\text { Locomotive Steam } \\
\text { Enginemen and Firemen } \\
\text { (ASLEF) }\end{array}$ & Trade union & Focused & 2011 & $\begin{array}{l}\text { Best Practice Guidelines for } \\
\text { Menopause }\end{array}$ & 8 pages & No longer available online \\
\hline
\end{tabular}




\begin{tabular}{|c|c|c|c|c|c|c|c|}
\hline 17. & $\begin{array}{l}\text { Trade Union Congress } \\
\text { (TUC) }\end{array}$ & Trade Union & Focused & 2011 & $\begin{array}{l}\text { Supporting Working Women } \\
\text { through the Menopause: } \\
\text { Guidance for Union } \\
\text { Representatives on Dealing } \\
\text { with Issues around the } \\
\text { Menopause }\end{array}$ & 6 pages & $\begin{array}{l}\text { https://www.tuc.org.uk/sites/ } \\
\text { default/files/extras/supportin } \\
\text { g_women_through_the_men } \\
\text { opause.pdf }\end{array}$ \\
\hline 18. & $\begin{array}{l}\text { Transport Salaried Staffs' } \\
\text { Association (TSSA) }\end{array}$ & Trade Union & Focused & 2011 & $\begin{array}{l}\text { Supporting Women through } \\
\text { the Menopause }\end{array}$ & 2 pages & $\begin{array}{l}\text { https://www.tssa.org.uk/en/u } \\
\text { tilities/search- } \\
\text { results.cfm/page/557/ }\end{array}$ \\
\hline 19. & $\begin{array}{l}\text { British Occupational } \\
\text { Health Research } \\
\text { Foundation }\end{array}$ & $\begin{array}{l}\text { Employers' } \\
\text { Research } \\
\text { Charity }\end{array}$ & Focused & 2010 & $\begin{array}{l}\text { Work and the Menopause: A } \\
\text { Guide for Managers }\end{array}$ & 3 pages & $\begin{array}{l}\text { http://www.bohrf.org.uk/dow } \\
\text { nloads/Work and the Meno } \\
\text { pause- } \\
\text { A Guide for Managers.pd }\end{array}$ \\
\hline 20. & $\begin{array}{l}\text { Transport \& General } \\
\text { Workers Union } \\
\text { (TGWU/T\&G) }\end{array}$ & Trade Union & Focused & 2007 & $\begin{array}{l}\text { T\&G Factsheet: Menopause } \\
\text { - Health, Safety, and } \\
\text { Workplace Issues }\end{array}$ & 16 pages & TUC Library, London \\
\hline 21. & Unite & Trade Union & Focused & 2007 & $\begin{array}{l}\text { UNITE Factsheet: Meeting } \\
\text { the Menopause - Health, } \\
\text { Safety, and Workplace Issues }\end{array}$ & 15 pages & TUC Library, London \\
\hline 22. & $\begin{array}{l}\text { Transport \& General } \\
\text { Workers Union } \\
\text { (TGWU/T\&G) }\end{array}$ & Trade Union & Focused & 2006 & $\begin{array}{l}\text { T\&G Factsheet: Meeting the } \\
\text { Menopause - Health, Safety, } \\
\text { and Workplace Issues }\end{array}$ & 15 pages & TUC Library, London \\
\hline
\end{tabular}




\begin{tabular}{|l|l|l|l|l|l|l|l|}
\hline 23. & $\begin{array}{l}\text { Transport Salaried Staffs' } \\
\text { Association (TSSA) }\end{array}$ & Trade Union & Focused & 2003 & $\begin{array}{l}\text { The Menopause - A } \\
\text { Workplace Issue }\end{array}$ & $\begin{array}{l}2 \text { pages } \\
\text { https://www.tssa.org.uk/en/u } \\
\text { tilities/search- } \\
\text { results.cfm/page/557/ }\end{array}$ \\
\hline 24. & $\begin{array}{l}\text { Trade Union Congress } \\
\text { (TUC) }\end{array}$ & Trade union & Focused & 2003 & $\begin{array}{l}\text { Working through the } \\
\text { Change: Health and Safety } \\
\text { and the Menopause }\end{array}$ & $\begin{array}{l}\text { 23 pages } \\
\text { https://www.tuc.org.uk/resea } \\
\text { rch-analysis/reports/working- } \\
\text { through-change-health-and- } \\
\text { safety-and-menopause }\end{array}$ \\
\hline 25. & $\begin{array}{l}\text { Trade Union Congress } \\
\text { (TUC) }\end{array}$ & Trade Union & Embedded & 1991 & $\begin{array}{l}\text { Women's Health at Risk-A } \\
\text { TUC Handbook }\end{array}$ & $\begin{array}{l}62 \text { pages (1 } \\
\text { page focused } \\
\text { on } \\
\text { menopause) }\end{array}$ & \begin{tabular}{l} 
TUC Library, ndon \\
\hline
\end{tabular} \\
\hline
\end{tabular}

Table 1: UK guidance documentation about menopause and work 


\begin{tabular}{|l|l|}
\hline THEME & BRIEF DESCRIPTION \\
\hline Legislation & $\begin{array}{l}\text { Referencing employers' common law duty of care and to their } \\
\text { duties to comply with requirements embodied in the Management } \\
\text { of Health and Safety at Work Regulations and the Equality Act }\end{array}$ \\
\hline Policies & $\begin{array}{l}\text { Describing policies that could or did include coverage of } \\
\text { menopause: those relating to sickness absence, flexible working } \\
\text { and health and wellbeing }\end{array}$ \\
\hline $\begin{array}{l}\text { Information } \\
\text { and training }\end{array}$ & $\begin{array}{l}\text { Suggesting provision of information, advice and training for staff, } \\
\text { including line managers, trade union representatives, and } \\
\text { menopausal women }\end{array}$ \\
\hline $\begin{array}{l}\text { Workplace } \\
\text { Support }\end{array}$ & $\begin{array}{l}\text { Depicting support from occupational health, human resources, } \\
\text { trade union representatives, GPs, line managers, counsellors, } \\
\text { EAPs, peers, welfare officers, a named contact person. }\end{array}$ \\
\hline $\begin{array}{l}\text { Physical work } \\
\text { environment }\end{array}$ & $\begin{array}{l}\text { Advocating the provision of: cold drinking water, rest areas, } \\
\text { sanitary or toilet facilities; suitable workplace temperature control } \\
\text { and ventilation; appropriate fabrics for uniforms. }\end{array}$ \\
\hline
\end{tabular}

Table 2: Themes identified in guidance about menopause and work 


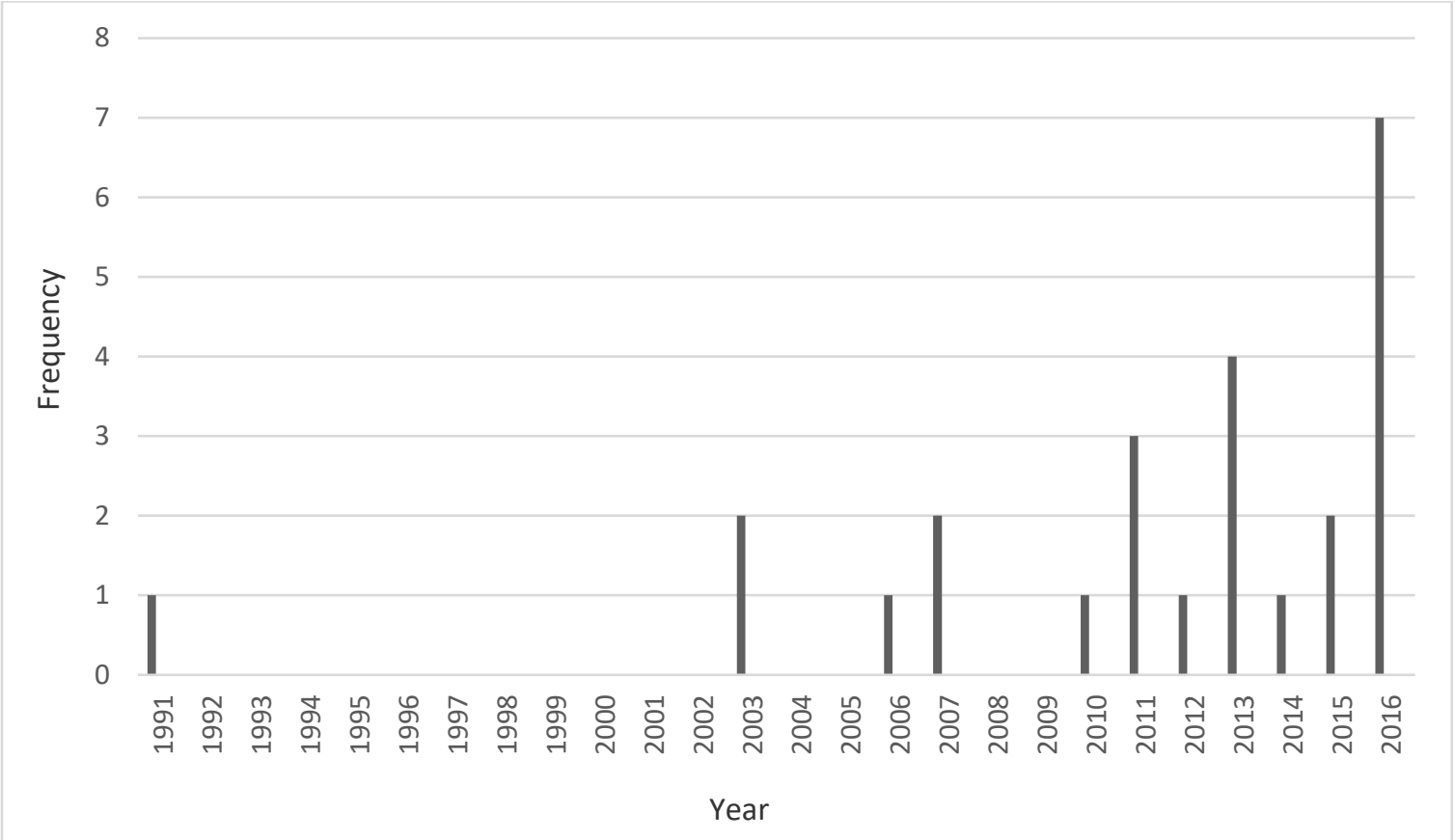

Figure 1: The number of published guidance about menopause and work over time (years) 